\section{IMPLEMENTASI INOVASI PENGELOLAAN KELAS DALAM MENGEMBANGKAN PEMBELAJARAN PENDIDIKAN AGAMA ISLAM DI SMK SUNAN KALIJOGO JABUNG MALANG}

\author{
Endang Tyasmaning \\ Institut Agama Islam Sunan Kalijogo Malang \\ etyasmaning@gmail.com
}

\begin{abstract}
Abstrak. Inovasi dalam meningkatkan kreatifitas dalam pengelolaan kelas dengan melaksanakan pelatihan tentang inovasi pengelolaan kelas. Kedua, Bagi lembaga dalam meningkatkan pendidikan dan pelatihan dengan melaksanakan kegiatankegiatan pengembangan inovasi pembelajaran, antara lain dengan cara melakukan observasi terhadap pengelolaan kelas yang dilakukan oleh guru ketika dalam proses belajar mengajar untuk dijadikan bahan evaluasi, dan melakukan penyuluhan kepada guru di SMK Sunan Kalijogo Jabung Malang. Lembaga pendidikan dalam mengembangkan dan meningkatkan inovasi pengelolaan kelas, dengan menggunakan teori-teori dan inovasi pengelolaan kelas yang terbarukan. Dan kepada kepala sekolah dan guru selalu memberikan inovasi-inovasi yang lebih baik, untuk peningkatan pemahaman dalam usaha melakukan inovasi pengelolaan kelas.
\end{abstract}

Kata Kunci : Inovasi Pengelolaan Kelas, Pembelajaran Pendidikan Islam

\begin{abstract}
Innovation in increasing creativity in classroom management by conducting training on classroom management innovation. Second, for institutions in improving education and training by carrying out learning innovation development activities, among others, by observing classroom management carried out by teachers during the teaching and learning process to be used as evaluation materials, and conducting counseling to teachers at Sunan Kalijogo Vocational School. Malang Jabung. Educational institutions in developing and improving classroom management innovations, by using up-to-date classroom management theories and innovations. And principals and teachers always provide better innovations, to increase understanding in an effort to innovate classroom management.
\end{abstract}

Keywords: Classroom Management Innovation, Islamic Education Learning

\section{PENDAHULUAN.}

Pengelolaan ruang kelas merupakan salah satu cara yang dapat menciptakan keefektifan dalam proses belajar mengajar, maka penataan dan pengeloaan ruang kelas perlu ditingkatkan dan dikembangkan agar seorang guru dapat menyediakan kondisi belajar yang optimal dengan suasana yang menyenangkan untuk mencapai tujuan pembelajaran. Pengelolaan kelas adalah menciptakan dan memelihara kondisi belajar yang optimal dan mengembalikannya ke kondisi yang optimal jika terjadi gangguan, baik 


\section{muhadasah \\ Jurnal Pendidikan Bahasa Arab \\ INSTITUT AGAMA ISLAM SUNAN KALIJOGO MALANG \\ P-ISSN 2622-6723 E-ISSN 2721-9488 \\ Volume 3, Nomor 2 Desember 2021}

secara yang mendisiplinkan ataupun melakukan kegiatan remedial atau perbaikan" (Hasibuan dan Moejiono, 1993:42).

Begitu juga menurut Bakri (2001:22) pengelolaan kelas adalah: "Proses dan pengorganisasian guru dalam menciptakan dan memelihara kondisi belajar yang optimal, dan keterampilan untuk mengembalikan kondisi belajar yang optimal, apabila terdapat gangguan dalam proses belajar mengajar baik yang bersifat gangguan kecil, sementara maupun gangguan yang bersifat besar dan berkelanjutan".

Dalam perkembangan dan peneingkatan pembelajaran di SMK Sunan Kalijogo Jabung Malang, jika ditinjau dari peran serta siswa, tanggapan masyarakat dan model pembelajaran dapat dikategorikan baik, dengan melihat sebagaian besar siswa dan masyarakat dan model pembelajaran dapat dikategorikan baik, dengan melihat sebagian besar siswa dan masyarakat senang dalam menerima inovasi pembelajaran yang dilakukan oleh guru dan banyaknya model pembelajaran yang dilakukan oleh para guru. Dan jika ditinjau dari profesionalisme guru dapat dikategorikan baik, dengan melihat tinkat pendidikan terakhir sebagian besar guru adalah lulusan sarjana, akan tetapi jika ditinjau dari kesesuai pendidikan terakhir dengan materi pelajaran yang diajarkan dikategorikan kurang, dengan melihat sebagian besar dari mereka dalam mengajar mata pelajaran belum sesuai dengan pendidikan terakhir. Dan jika ditinjau dari bentuk kurikulum yang digunakan dapat dikategorikan baik, dengan melihat kessesuaian antara kurikulum yang digunakan yakni kurikulum KTSP yang mana dalam proses belajar mengajar menerapkan materi pembelajaran dalam kehidupan sehari-hari. dan jika ditinjau dari media pembelajaran juga baik karena media yang digunakan kebanyakan menggunakan media yang ada di lingkungan sekolah dan media-media lain yang buat sendiri oleh gurunya.

Sekolah sebagai suatu lembaga pendidikan formal secara sistematis merencanakan bermacam-macam lingkungan pendidikan. Lingkungan belajar yang baik adalah apabila bersifat menantang dan merangsang murid-murid bejar, serta memberikan rasa aman dan kepuasan. Kualitas dan kuantitas belajar murid tergantung pada murid-murid dalam kelas, bahan-bahan pelajaran dan suasana didalam kelas, karena kondisi sebuah ruang kelas merupakan salah satu cara yang dapat menentukan keberhasilan pembelajaran, maka penataan dan pengelolaan ruang kelas perlu 


\section{muhadasah \\ Jurnal Pendidikan Bahasa Arab \\ INSTITUT AGAMA ISLAM SUNAN KALIJOGO MALANG \\ P-ISSN 2622-6723 E-ISSN 2721-9488 \\ Volume 3, Nomor 2 Desember 2021}

ditingkatkan dan dikembangkan. Oleh karena itu, sekolah berfungsi sebagai tempat anak dan pendidik melaksanakan kegiatan belajar mengajar. Dua kegiatan tersebut mempunyai tujuan untuk mengembangkan kemampuan intelektual sekaligus pembentukan pribadi anak.

Melihat kenyataan yang paling menonjol tentang bagaimana metode guru dalam menyampaikan materi pelajaran, yang sampai saat ini mayoritas masih hanya menggunakan metode ceramah tanpa menggunakan media atau alat pembelajaran yang telah ada, padahal berdasarkan realita yang ada seorang siswa memiliki daya serap yang rendah terhadap informasi dan hafalan, dan kebanyakan dari mereka lebih mudah menangkap atau menerima sebuah pelajaran, apabila mereka mengalaminya sendiri. Untuk itu, dibutuhkan adanya sebuah inovasi dalam pendidikan dan pembelajaran, sangat diperlukan terutama dalam hal pengelolaan kelas. Berawal dari permasalahan di atas, akhirnya peneliti tertarik untuk mengangkat sebuah judul "Implementasi Inovasi Pengelolaan Kelas dalam Mengembangkan Pembelajaran Pendidikan Agama Islam di SMK Sunan Kalijogo Jabung Malang.

Kegiatan belajar mengajar dengan pola yang tidak sama, khususnya dalam hal inovasi pengeloaan kelas, dalam menggunakan sarana prasarana selalu disertai dengan adanya sebuah praktek, sehingga peserta didik dapat memperoleh pengetahuan dengan cara menemukan sendiri dan mereka dapat menghafal lebih cepat apa yang sedang mereka pelajari, juga adanya pola tata ruang kelas yang menyenangkan serta kondisi pembelajaran yang tidak selalu sama setiap harinya. Hal ini dimaksudkan untuk menghindari kebosanan dan kemalasan sehingga dapat menimbulkan semangat siswa dalam melakukan kegiatan belajar.

Dengan adanya Inovasi Pengelolaan kelas di atas diharapkan program dan kegiatan belajar mengajar, mampu membantu dalam mengembangkan dan meningkatkan suasana belajar yang efektif dan efisien, sehingga an menjadi nyaman dan menyenangkan.

\section{KAJIAN TEORI}

Pengelolaan kelas dapat didefinisikan secara luas, tergantung sudut pandang yang ingin digunakan. Beberapa definisi mengenai pengelolaan kelas menurut para ahli adalah sebagai berikut: Pengelolaan kelas adalah suatu usaha yang dilakukan oleh penanggung 


\section{muhadasah \\ Jurnal Pendidikan Bahasa Arab \\ INSTITUT AGAMA ISLAM SUNAN KALIJOGO MALANG \\ P-ISSN 2622-6723 E-ISSN 2721-9488 \\ Volume 3, Nomor 2 Desember 2021}

jawab kegiatan belajar mengajar atau yang membantu dengan maksud agar dicapai kondisi optimal sehingga dapat terlaksana kegiatan belajar seperti yang diharapkan (Arikunto,1992:68). Pendapat di atas menjelaskan bahwa pengelolaan kelas merupakan suatu usaha yang dilakukan guru yang sedang berada di kelas dengan tujuan untuk menciptakan kondisi kelas yang nyaman dan menyenangkan sehingga tercapai tujuan pembelajaran secara efektif dan efisien. Di lain pihak, Cece (1992:113) berpendapat bahwa pengelolaan kelas adalah usaha dari pihak guru untuk menata kehidupan kelas yang dimulai dari perencanaan kurikulumnya, penataan prosedur dan sumber belajarnya, lingkungannya untuk memaksimalkan efisiensi, memantau kemajuan siswa dan mengantisipasi masalah-masalah yang mungkin timbul. Berdasarkan pendapat Cece di atas tergambar bahwa pengelolaan kelas adalah usaha yang dilakukan guru dalam menata kehidupan kelas yang dimulai dari perencanaan kurikulum, penataan sumber belajar, penataan lingkungan kelas, 22 dan memantau kemajuan siswa serta mengantisipasi masalah-masalah yang timbul di dalam kelas pada saat pembelajaran. Jika memperhatikan pendapat Cece di atas, pengelolaan kelas mencakup hal-hal yang menyeluruh yakni dimulai dari perencanaan sampai dengan usaha mengantisipasi masalah-masalah yang mungkin timbul di dalam kelas. Khusus dalam penelitian ini, pengelolaan kelas hanya dibatasi pada penataan lingkungan kelas dan pengantisipasian masalah-masalah yang mungkin timbul di dalam kelas yang terdiri dari penataan ruang kelas, pengembangan hubungan interpersonal, penegakan disiplin, pemberian hadiah dan hukuman, dan penanggulangan perilaku siswa yang menyimpang dan bersifat kronis.

\section{METODE}

Dalam penelitian ini menggunakan studi kasus kualitatif, dikarenakan untuk mengeksplorasikan perihal kasus penelitian dan memfokuskan pada individu atau kelompok, dengan mendiskripsikan kasus yang diperinci (kasus intrinsik), begitu juga satu kasus atau dengan beberapa kasus (kasus intrumental). Sedangkan dalam pendekatan studi kasus ini adalah: penekananya berfokus pada identifikasi satu situs dan atau multi situs, (John W Creswell, (2010). Dan metode penelitian ini digunakan dalam semua mata pelajaran, oleh seorang guru harus dapat memilih ketetapan yang akan 


\section{muhadasah \\ Jurnal Pendidikan Bahasa Arab \\ INSTITUT AGAMA ISLAM SUNAN KALIJOGO MALANG \\ P-ISSN 2622-6723 E-ISSN 2721-9488 \\ Volume 3, Nomor 2 Desember 2021}

digunakannya, sehingga sesuai dengan pembahasan yang sedang dilakukan. Dan untuk metode pembelajaran yang digunakan diantaranya: 1) Metode Demontrasi yakni metode pengajaran yang menuntut adanya praktek atau peragaan dengan menggunakan media atau alat bantu berupa benda fisik, dan tergantung atas materinya. 2) Metode Pengunjungan Studi yaitu metode pengajaran yang pelajaran dengan mengadakan kunjungan kesuatu obyek dfiluar kelas dengan mengjikan bahan maksud utama mempelajari obyek yang sesuai dengan materi pembelajaran.

Teknik yang digunakan dalam pengelolaan dan mendisiplinkan kelas, yaitu: Pertama Campur tangan dengan isyarat. Sikap seperti ini dilakukan ketika terjadi gangguan yang bersifat kecil, seperti suasana gaduh ketika proses belajar mengajar berlangsung. Kedua Mengawasi dari dekat. Hal ini dilakukan agar dapat menyediakan proses belajar mengajar yang optimal dengan suasana belajar yang menyenangkan. Ketiga Mengungkapkan perasaan siswa. Yakni agar siswa dalam belajar tidak merasa tertekan sehingga menjadi siswa yang pasif melainkan menjadi siswa yang aktif dan kreatif. Keempat Menyusun kembali program belajar. Kelima menghilangkan ketegangan dengan humor. Hal ini dilakukan agar dapat menciptakan kehangatan dan keantusiasan siswa dalam belajar. Keenam pendekatan fisik. Seperti membelai kepala siswa, Menepuk pundak siswa dengan maksud memberi motivasi kepada siswa akan terdorong untuk belajar lebih baik lagi.

\section{HASIL DAN PEMBAHASAN}

Sekolah sebagai suatu lembaga pendidikan formal secara sistematis merencanakan bermacam-macam lingkungan pendidikan. Lingkungan belajar yang baik adalah apabila bersifat menantang dan merangsang murid-murid bejar, serta memberikan rasa aman dan kepuasan. Kualitas dan kuantitas belajar murid tergantung pada peserta didik dalam kelas, bahan-bahan pelajaran dan suasana didalam kelas, karena kondisi sebuah ruang kelas merupakan salah satu cara yang dapat menentukan keberhasilan pembelajaran, maka penataan dan pengelolaan ruang kelas perlu ditingkatkan dan dikembangkan. Oleh karena itu, sekolah berfungsi sebagai tempat anak dan pendidik melaksanakan kegiatan belajar mengajar. Dua kegiatan tersebut mempunyai tujuan untuk mengembangkan kemampuan intelektual sekaligus pembentukan pribadi anak. 


\section{muhadasah \\ Jurnal Pendidikan Bahasa Arab \\ INSTITUT AGAMA ISLAM SUNAN KALIJOGO MALANG \\ P-ISSN 2622-6723 E-ISSN 2721-9488 \\ Volume 3, Nomor 2 Desember 2021}

Dari sebuah kegiatan belajar mengajar (KBM) seseorang yang belum melakukan dan yang sudah melakukan KBM sebenarnya tidak sama keadaannya. Dengan pesatnya kemajuan teknologi sumber pembelajaran mudah diperoleh namun beberapa guru atau pengajar tetap sangat diperlukan, sebab dalam KBM guru merupakan seseorang yang patut diteladani, baik oleh murid maupun masyarakat sekitarnya, maka tugas guru bukan hanya mentransfer pengetahuan tetapi juga membentuk kepribadian anak didiknya, dengan demikian tugas seorang guru sangatlah besar tetapi juga sangat mulia.

Inovasi pengelolaan kelas guna untuk mengembangkan dinamika pembelajaran di sekolah, dalam melakukan inovasi pembelajaran di sekolah, yang tidak lain bertujuan pelaksanaannya adalah mengembangkan dinamika/kegiatan pembelajaran. Adapun bentuk-bentuk inovasi adalah:

a. Inovasi dalam segi model pembelajaran.

Dalam inovasi penataan ruangan kelas ini, inovasi yang telah dilakukan oleh SMK Sunan Kalijogo Jabung Malang sebagai perkembangan, pembaharuan, dan perubahan guna meningkatkan mutu pendidikan. Dalam inovasi model pembelajaran ini, inovasi yang telah dilakukan di SMK Sunan Kalijogo Jabung Malang, Penggunaan Model pembelajaran Integratif Learning (Tematik)

Dalam bentuk pembelajaran Intregatif Learning atau tematik pembelajaran di SMK Sunan Kalijogo Jabung Malang, pembelajaran dilakukan dengan cara pengelompokkan tema dari mata pelajaran, yakni: dalam satu mata pelajaran, sebuah topik materi pelajaran tidak di potong-potong, tetapi antara topik setiap satu pelajaran dengan pelajaran yang lain saling berhubungan. Misalnya ketika dalam pelajaran bahasa Indonesia yang bertemakan masalah budi pekerti, maka dalam pelajaran PPKn juga bertemukan kemurahan hati, dalam pelajaran IPA (sains) bertemukan benda padat dan cair, begitu seterusnya dengan mata pelajaran yang lain juga disesuaikan. Hal ini dilakukan agar mata pelajaran yang ada dalam satu minggu dapat tercakup semua. Sehingga dari adanya kesamaan tema dalam setiap pelajaran dapat diterapkan sekaligus dalam satu hari, yakni di hari sabtu (one day discovery), dimana siswa diajak belajar di luar kelas dengan cara mengunjungi obyek tertentu, menjelajah, dan bertualangan sambil belajar. Dan dari semua mata 


\section{muhadasah \\ Jurnal Pendidikan Bahasa Arab \\ INSTITUT AGAMA ISLAM SUNAN KALIJOGO MALANG \\ P-ISSN 2622-6723 E-ISSN 2721-9488 \\ Volume 3, Nomor 2 Desember 2021}

pelajaran yang ada, hanya diambil satu yang menurut pertimbangan guru paling sesuai atau cocok dengan tema untuk diterapkan oleh peserta didik.

Model pembejaran seperti yang diuraikan di atas, dilakukan dengan tujuan agar pembelajaran dapat berjalan optimal sesuai dengan tujuan kurikulum. Model pembejaran sebagai berikut:

1. Penggunaan Model Pembelajaran Joiful Learning.

Dalam model pembelajaran joiful learning (belajar sambil bermain) di MI Raden Rahmat Sunan Ampel Gerbo, pembelajaran dilakukan dengan cara santai dan menyenangkan, yakni mempelajaru sebuah mata pelajaran dengan menerapkan pengalaman secara langsung sesuai dengan tema pelajaran yang ada. Misal: ketika dalam pelajaran PPKn dengan tema tolong menolong antar manusia, maka guru mengajak semua siswa turun langsung ke masyarakat bagaimana melakukan perbuatan tolong menolong sesame manusia suatu misal kerja bakti lingkungan, dan membantu anak yatim, dan pada saat pelajaran matematika, bab pengurangan. Maka guru menyuruh kepada setiap siswa untuk mencari dan membawah beberapa ikan, yang kemudian ikan-ikan tersebut di masukkan ke dalam aquarium yang di sediakan oleh guru, setelah itu guru menyuruh kepada siswa untu menhitung ada berapa jumlah ikan di dalam aquarium dan warnanya apa saja. Setelah itu guru memindahkan beberapa ikan yang ada di dalam aquarium ke tempat lain, kemudian guru menyuruh sekali lagi kepada siswa untuk menghitung kembali berapa jumlah ikan yang ada di dalam aquarium setelah mengurangi jumlahnya.

Model pembelajaran seperti ini, dilakukan dengantujuan agar siswa mudah dalam memahami mata pelajaran.

2. Pengunaan Model Pembelajaran Life Skill.

Dalam model Pembelajaran Life Skill (kecakapan hidup) di MI Raden Rahmat Sunan Ampel Gerbo, pembelajaran dilakukan dengan cara menyuruh siswa untuk melakukan segala hal dengan kemampuan yang mereka miliki. Misal: ketika dalam pelajaran bahasa Indonesia dengan tema/bab pasar. Maka guru memberi tugas kepada siswa untuk pergi ke pasar dan berbelanja, hal ini dilakukan dengan tujuan supaya siswa dapat mengetahui secara langsung bagainama keadaan sebuah pasar. 


\section{muhadasah \\ Jurnal Pendidikan Bahasa Arab \\ INSTITUT AGAMA ISLAM SUNAN KALIJOGO MALANG \\ P-ISSN 2622-6723 E-ISSN 2721-9488 \\ Volume 3, Nomor 2 Desember 2021}

Sekaligus siswa juga dapat mempelajari pelajaran matematika, yakni ketika mereka melakukan interaksi dengan penjual, dimana siswa melakukan pembayaran.

Model pembelajaran seperti ini, dilakukan dengan tujuan agar siswa sanggup dan mampu dalam melakukan sesuatu dengan sendirinya, dalam kata lain melatih untuk dapat mandiri.

3. Penggunaan Metode Pembelajaran Worksheet.

Dalam model pembelajaran Worksheet yang merupakan lembar kerja siswa. Pembelajaran dilakukan dengan cara guru memberikan satu lembar soal kepada semua siswa, yang di dalamnya tidak hanya berisikan soal-soal yang harus dijawab, tetapi juga terdapat sebuah gambaran yang harus mereka warnai. Misal: ketika dalam pelajaran bahasa Indonesia dengan tema lingkungan, maka guru memberi tugas/lembar kerja pada sisiwa, yang di dalamnya terdapat gambar berupa lingkungan yang kemudian mereka harus mewarnainya sekaligus menjawab pertanyaan-pertanyaanyang di dalamnya. Begitu juga dengan pelajaran yang lainnya.

Hal ini dilakukan dengan tujuan agar siswa dalam mengerjakan latihan soal dari guru merasa nyaman sehingga tidak ada perasaan tertekan.

\section{KESIMPULAN}

Berdasarkan hasil penelitian di lapangan, maka dapat disimpulkan bahwa inovasi pengelolaan kelas dalam mengembangkan dinamika pembelajaran di SMK Sunan Kalijogo Jabung Malang, dapat dikategorikan berhasil, terbukti dari adanya inovasi atau pembaharuan dalam segi penataan kondisi atau keadaan ruang kelas maupun metode pembelajaran. Dan melihat kenyataan yang terjadi banyaknya perubahan yang ada, baik dalam hal kondisi tempat duduk yang tidak hanya terdiri dari sebuah bangku melainkan juga adanya karpet, penggunaan media papan, dan media perkebunan di lingkungan sekolah, jumlah kelas dan juga banyaknya metode pembelajaran yang telah dilakukan.

Perkembangan dinamika pembelajaran di SMK Sunan Kalijogo Jabung Malang, jika ditinjau dari peran serta siswa, tanggapan masyarakat dan model pembelajaran dapat dikategorikan baik, dengan melihat sebagaian besar siswa dan masyarakat dan model pembelajaran dapat dikategorikan baik, dengan melihat sebagian besar siswa dan 


\section{muhadasah \\ Jurnal Pendidikan Bahasa Arab \\ INSTITUT AGAMA ISLAM SUNAN KALIJOGO MALANG \\ P-ISSN 2622-6723 E-ISSN 2721-9488 \\ Volume 3, Nomor 2 Desember 2021}

masyarakat senang dalam menerima inovasi pembelajaran yang dilakukan oleh guru dan banyaknya model pembelajaran yang dilakukan oleh para guru. Dan jika ditinjau dari profesionalisme guru dapat dikategorikan baik, dengan melihat tinkat pendidikan terakhir sebagian besar guru adalah lulusan sarjana, akan tetapi jika ditinjau dari kesesuai pendidikan terakhir dengan materi pelajaran yang diajarkan dikategorikan kurang, dengan melihat sebagian besar dari mereka dalam mengajar mata pelajaran belum sesuai dengan pendidikan terakhir. Dan jika ditinjau dari bentuk kurikulum yang digunakan dapat dikategorikan baik, dengan melihat kesesuaian antara kurikulum yang digunakan yakni kurikulum KTSP yang mana dalam proses belajar mengajar menerapkan materi pembelajaran dalam kehidupan sehari-hari. dan jika ditinjau dari media pembelajaran juga baik karena media yang digunakan kebanyakan menggunakan media yang ada di lingkungan sekolah dan mediamedia lain yang buat sendiri oleh gurunya. Faktor pendukung inovasi pengelolaan kelas dalam mengembangkan dinamika pembelajaran di SMK Sunan Kalijogo Jabung Malang, adalah: adanya dukungan dari DIKNAS, adanya sarana prasarana pembelajaran yang cukup memadai, adanya kerja sama dan motifasi antar sesama guru dalam menciptakn mutu pembelajaran yang lebih baik, adanya studi banding dan partisipasi siswa dalam menerima inovasi pembelajaran. Dari paparan data di atas maka dapat disimpulkan sebagai berikut:

Pertama, Bagi guru agar lebih meningkatkan lagi kreatifitas dalam pengelolaan kelas dengan cara mengikuti pelatihan, memperbanyak membaca buku maupun media masa tentang inovasi pengelolaan kelas.

Kedua, Bagi lembaga agar dapat lebih meningkatkan kegiatan-kegiatan inovasinya, dengan cara dapat sesering mungkin melakukan observasi terhadap pengelolaan kelas yang dilakukan oleh guru ketika dalam proses belajar mengajar untuk dijadikan bahan evaluasi, dan melakukan penyuluhan kepada guru di SMK Sunan Kalijogo Jabung Malang, tentang bagaimana pengelolaan kelas yang baik.

Ketiga lembaga pendidikan untuk dapat meningkatkan dan mengembangkan dan meningkatkan inovasi pengelolaan kelas, dengan menggunakan teori-teori dan inovasi pengelolaan kelas yang terbarukan. Dalam penelitian ini masih sangat sederhana. Oleh karena itu, di harapkan kepada kepala sekolah dan guru untuk lebih lanjut memberikan inovasi yang lebih baik, untuk peningkatan pemahaman dalam usaha melakukan inovasi pengelolaan kelas. 


\section{DAFTAR PUSTAKA}

Ahamadi, Abu dan Uhbiyati, Nur. 2001. Ilmu Pendidikan, Jakarta: PT. Rineka Cipta.

Aly, Hery Noer. 1999. Ilmu Pendidikan Islam. Jakarta: PT. Logos Wacana ILmu.

Arifin, Anwar. 2003. Memahami Paradigma Baru dalam UU SISDIKNAS, Jakarta: Departemen Agama RI.

Arikunto, Suharsimi. 2002. Prosedur Pendampingan "Suatu Pendekatan Praktek". Jakarta: PT. Rineka Cipta.

Arikunto, Suharsimi. 1998. Pengelolaan Kelas dan Siswa "Sebuah Pendekatan Evaluasi". Jakarta: CV. Rajawali.

Bakri, Masykuri. 2001. Micro Teaching. Medio.

Danim, Sudarwan. 2002. Inovasi Pendidikan " dalam Upaya Peningkatan Prpfesionalisme Tenaga Kependidikan". Bandung: CV. Pustaka Setia.

Darajat, Zakiyah. 1996. Metodologi Pendidikan Agama Islam. Jakarta: Bumi Aksara.

Departemen Agama RI. 1999. Petunjuk Peningkatan Mutu Pendidikan di Madrasah Ibtidaiyah (MI). Jakarta: Departemen Agama RI.

Faisal, Sanapiah. 2001. Format-format Pendampingan Sosial. Jakarta: PT. Raja Grafindo Persada.

Hadi, Sutrisno. 2001. Metodelogi Research, jilid 2. Yogyakarta: ANDI.

Hanalik, Oemar. 2003. Perencanan Pengajaran Berdasarkan Pendekatan Sistem. Jakarta: PT: Bumi Aksara.

Hasibuan dan Moedjiono.1993. Proses Belajar mengajar. Bandung: PT. Remaja Rosdakarya.

Moleong, Lexy J. 2002. Metodelogi Pendampingan Kualitatif. Bandung: PT. Remaja Rosdakarya.

Muhadjir, Noeng. 1998. Metodelogi Kualitatif. Yogyakarta: PT Bayu Indra Grafika.

Namsa, Yunus. 2000. Metodelogi Pengajaran Agama Islam. Ternate: Pustaka Firdaus.

Rakhman, Maman. 1993. Strategi dan Langkah-Langkah Pendampingan Pendidikan. Semarang: IKIP Semarang Press.

Rama K, Tri. Kamus Praktis Bahasa Indonesia dilengkapi dengan: Pedoman Umum Ejaan Bahasa Indonesia yang disempurnakan. Surabaya: Karya Agung.

Santoso, Slamet. 1999. Dinamika Kelompok. Jakarta: Bumi Aksara.

Sedarmayanti dan Hidayat. 2002. Metodelogi Pendampingan Sosial Agama. Bandung: PT. Remaja Rosdakarya.

Suprayogo dan Tobroni. 2003. Metodelogi Pendampingan. Jakarta: CV. Rajawali. 
Suryosubroto. 2004. Manajemen Pendidikan di Sekolah. Jakarta: PT. Rineka Cipta.

Tim Penyusun Panduan Skripsi. 2008. Panduan Penulisan Skripsi. Pasuruan: Universitas Yudharta Pasuruan.

Wijaya, C, Djadjuri, Djadja dan Rusyan, Tabrani. 1992. Upaya Pembaharuan dalam Pendidikan dan Pengajar 